\title{
Do Archaea and bacteria co-infection have a role in the pathogenesis of chronic chagasic cardiopathy?
}

\author{
Maria de Lourdes Higuchi $/{ }^{+}$, Joyce Kawakami, Renata Ikegami, Maysa Beatriz Mandetta Clementino, \\ Flavio M Kawamoto, Marcia M Reis, Edimar Bocchi
}

Laboratório de Anatomia Patológica, Instituto do Coração, Faculdade de Medicina, Universidade de São Paulo, Av. Dr. Enéas de Carvalho Aguiar 44, 05403-000 São Paulo, SP, Brasil

Chronic cardiopathy (CC) in Chagas disease is a fibrotic myocarditis with C5b-9 complement deposition. Mycoplasma and Chlamydia may interfere with the complement response. Proteolytic enzymes and archaeal genes that have been described in Trypanosoma cruzi may increase its virulence. Here we tested the hypothesis that different ratios of Mycoplasma, Chlamydia and archaeal organisms, which are frequent symbionts, may be associated with chagasic clinical forms. Materials and methods: eight indeterminate form (IF) and 20 CC chagasic endomyocardial biopsies were submitted to in situ hybridization, electron and immunoelectron microscopy and PCR techniques for detection of Mycoplasma pneumoniae (MP), Chlamydia pneumoniae (CP), C5b-9 and archaeal-like bodies. Results: MP and CP-DNA were always present at lower levels in CC than in IF $(p<0.001)$ and were correlated with each other only in CC. Electron microscopy revealed Mycoplasma, Chlamydia and two types of archaeal-like bodies. One had electron dense lipid content (EDL) and was mainly present in IF. The other had electron lucent content (ELC) and was mainly present in CC. In this group, ELC correlated negatively with the other microbes and EDL and positively with C5b-9. The CC group was positive for Archaea and T. cruzi DNA. In conclusion, different amounts of Mycoplasma, Chlamydia and archaeal organisms may be implicated in complement activation and may have a role in Chagas disease outcome.

Key words: Chlamydia pneumoniae - Mycoplasma pneumoniae - Archaea - Chagas disease - complement C5b-9

Chagas heart disease is described as a cardiomyopathy secondary to Trypanosoma cruzi infection. Antigens (Higuchi et al. 1993a, Bellotti et al. 1996, 1998) and DNA (Jones et al. 1993) from T. cruzi are found within the inflammatory infiltrate of the myocardium. The scarce amount of parasite product present is associated with an intense inflammatory infiltrate suggesting alternative mechanisms of pathogenesis (Higuchi et al. 2003a, Marin-Neto et al. 2007). One proposed theory is that the parasite releases polyclonal activators, which would favour the development of autoimmune injury (Gao et al. 2003). Alternatively, the presence of the parasite may alter myosin in such away that it would be recognized as non-self myosin by lymphocytes (Cunha-Neto et al. 1995). One theory not yet explored is the possible concomitance of additional infectious agents with $T$. cruzi.

Interactions between agents and co-infections have been reported in experimental studies with $T$. cruzi and in clinical reports of myocarditis (Andreoli et al. 2006, Cortez et al. 2006, Chimenti et al. 2007, Walder et al. 2007) and non-myocardial diseases. Mycoplasma and

Financial support: FAPESP, CNPq, Fundação Zerbini + Corresponding author: anplourdes@incor.usp.br Received 23 March 2009

Accepted 1 June 2009
Chlamydia are frequent symbionts (Horn \& Wagner 2004) and Mycoplasma in the cytoplasm of Trichomonas causes chronic resistant genital infection (Dessi et al. 2005). Biofilms may be involved in development of plaque vulnerability (Katz \& Shannon 2006). We have frequently found Mycoplasma pneumoniae and Chlamydia pneumoniae antigens in the coronary arteries and valves of normal hearts and in increased amounts in hearts affected by chronic inflammatory disorders involving stenotic aortic valves (Higuchi et al. 2002) and ruptured atherosclerotic plaques (Higuchi et al. 2000, 2003b). We observed that the intimal association between Mycoplasma and Chlamydia occurred in the presence of archaeal-like forms associated with myxoid matrix in vulnerable plaques (Higuchi et al. 2006b).

Archaea, one of the three domains of life, is a highly diverse and abundant group of prokaryotes and includes a number of "extremophiles" that thrive in such environments as hot springs, salt lakes and submarine volcanic habitats (Madigan et al. 2000). Recent molecular studies have also revealed that archaea, like bacteria, are commonly mesophilic (DeLong 1992).

Multiple archaeal genomes have been sequenced and a large number of Archaeal-like genes have been described in persistent pathogens. It has been suggested that archaeal genes may confer metabolic capabilities as adaptive strategies for survival, even in hostile host niches, by allowing them to breach host barriers that exclude other organisms (Srinivasan \& Morowitz 2006). This effort has contributed to a better understanding 
of archaeal cellular processes. Some archaeal characteristics, such as M32 metallo carboxypeptidase (MCP) and two types of proteasome similar to those found in a common archaeal-eubacterial ancestor, were described in T. cruzi (Niemirowicz et al. 2007, Gille et al. 2003). A microbial consortium between a bacterium and a phylogenetically, distantly related archaeon has been suggested to promote the growth of both microbes in freshwater and marine sediments (Boetius et al. 2000, Raghoebarsing et al. 2006).

However, over half of the archaeal genes encode unique proteins of unknown function and no definitive virulence genes or factors have been described in archaea to date. Archaea share access to their host and are capable of long-term colonization and coexistence with endogenous flora in the host. The detection of anaerobic archaea among the human colonic (Miller et al. 1982, Miller \& Wolin 1983), vaginal (Belay et al. 1990) and oral microbial flora (Belay et al. 1988) demonstrates their ability to colonize the human host. Details regarding their survival in such human niches, including their ability to evade the human immune system and compete with normal human flora, however, are practically unavailable (Eckburg et al. 2003).

Lepp et al. (2004) established correlations between the presence of disease and the presence of archaeal DNA, the severity of periodontal disease and the relative abundance of archaeal DNA in subgingival plaque, and between disease resolution and diminished archaeal DNA abundance. Archaeal genomes contain partial tad loci, which may encode Tad-like proteins involved in fibril formation and surface adherence (Lepp et al. 2004).

The complement system is a major component of innate immunity and provides an effective host defence mechanism against pathogens (Muller-Eberhard 1988). Mycoplasma may cause chronic disease in part by evading the immune response through antigenic variation and resistance to complement lysis (Simmons et al. 2004). The terminal complement complex C5b-9 was detected in the myocardium of chronic cardiac (CC) chagasic patients (Aiello et al. 2002). C5b-9 participates in several inflammatory and proliferative processes by releasing pro-inflammatory cytokines and growth factors from target cells. Sublytical doses of C5b-9 may promote cell proliferation (Niculescu et al. 1999, Halperin 1993) and participate in the development of severe fibrosis in chagasic cardiomyopathy.

We hypothesized that a consortium involving bacteria, archaea and $T$. cruzi might be related to different chronic chagasic disease outcomes, including CC and indeterminate asymptomatic form (IF). CC is associated with increased complement activation, fibrosis and lymphocytic myocarditis. IF is associated with the presence of Mycoplasma and Chlamydia, which leads to decreased complement activation and degradation of myosin, preventing an "auto-immune" reaction.

In the present work we investigated whether endomyocardial biopsies of CC or IF chagasic patients present forms and antigens or DNA from M. pneumoniae, C. pneumoniae or archaeal organisms, and whether they are associated with each other and with C5b-9.

\section{MATERIALS AND METHODS}

This work was approved by the Ethical and Scientific Committee of Heart Institute, University of São Paulo, Shool of Medicine, São Paulo, Brazil. We reviewed endomyocardial biopsies from chagasic patients with indeterminate or chronic cardiac forms, performed between 1980-2001 at the Heart Institute of São Paulo. We compared the amount of M. pneumoniae DNA (MPDNA), M. pneumoniae DNA (CP-DNA) and archaeallike bodies in myocardial fragments of chagasic patients with the IF versus CC form using in situ hybridization (ISH), immunoelectron microscopy, electron microscopy and PCR. As the fragments were too small, we could not use the same case for multiple techniques. Therefore, correlations between the results obtained with different techniques were not determined in this study. Archaealike bodies were quantified according to their morphology by electron microscopy since we do not have specific antibodies or probes. DNA from CC fragments was amplified with specific primers for the Archaea domain.

ISH analysis - in situ myocardial detection of MPDNA and CP-DNA by light microscopy - Serial sections of paraffin embedded endomyocardial biopsy fragments from 24 patients with Chagas disease were submitted to ISH for identification of MP-DNA and CP-DNA. Of the 24 fragments, seven were of indeterminate form (men age $34 \pm 11$ years, 3 males), and 17 were associated with heart failure ( $37 \pm 12$ years, 11 males).

Cell permeabilization was achieved using a $0.01 \mathrm{M}$ citrate buffered solution, $\mathrm{pH} 6.0 \pm 0.1$, in the microwave oven following the protocol for heat-induced target retrieval described for IHC. Endogenous peroxidase was blocked with $\mathrm{H}_{2} \mathrm{O}_{2}$ at $3 \%$ for $20 \mathrm{~min}$ at $37^{\circ} \mathrm{C}$. Tissue proteins were blocked with serum free protein block (Dako, Carpinteria, CA, USA) for $15 \mathrm{~min}$ at $37^{\circ} \mathrm{C}$. Next, $20 \mu \mathrm{L}$ of hybridization mixture containing the probe, deionized formamide, $50 \%$ dextran sulfate, $20 \mathrm{X}$ SSC, Denhardt solution, salmon sperm DNA, yeast tRNA, poly A and poly $\mathrm{C}$, and diethyl pyrocarbonate pure water, was applied to the sections and overlaid with a coverslip. The M. pneumoniae probe was prepared from a highly specific $M$. pneumoniae clone (Enzo Diagnosis, Farmingdale, NY, USA). The biotin-labelled $M$. pneumoniae oligonucleotide probe was synthesized by GIBCO/BRL (Rockville, MD, USA). The target DNA double-strands were denatured at $95 \pm 5^{\circ} \mathrm{C}$ for 6 min. DNA hybridization was performed for $18 \mathrm{~h}$ in a humidity chamber at $37^{\circ} \mathrm{C}$. After hybridization, the coverslip was removed with $0.05 \mathrm{M}$ Tris/ $\mathrm{HCl}$ and $0.003 \mathrm{mM} \mathrm{NaCl}, \mathrm{pH} 7.6$, containing $0.1 \%$ Tween 20. Non-specific hybrids were excluded with post hybridization washes in $0.2 \mathrm{xSS}$ for $10 \mathrm{~min}$ at $50^{\circ} \mathrm{C}$ and $2 \mathrm{x} \mathrm{SSC}$ for $10 \mathrm{~min}$ at $37^{\circ} \mathrm{C}$. The signal was amplified using the Catalyzed Signal Amplification system (Dako, Carpinteria, CA, USA). The reaction was visualized with chromogen 3,3-diaminobenzidine (Dako, Carpinteria, CA, USA) for $5 \mathrm{~min}$ at RT. Sections were counterstained with Harris' haematoxylin and mounted with Entellan resin (Merck, Darmstadt, Germany). Controls: negative controls were carried out by omitting the probe or the primary antibody. As a positive control for 
all reactions, we used human tissue sections known to be positive for M. pneumoniae and C. pneumoniae. In addition, as a positive control for ISH, we used a repetitive Alu sequence probe (alu1/alu2) by Genetic Research (Al, USA) and for negative control we used a plasmid DNA labelled with biotin (Dako, Carpinteria, CA, USA).

The positive brown dots that represent DNA of $M$. pneumoniae and C. pneumoniae were detected by an image analysis system (Quantimet-500 Leica) and the mean percentage area for each DNA in all EMB was obtained.

Electron microscopy quantification of archaea by ultrastructural morphology and M. pneumoniae and C. pneumoniae by immune staining - Araldite embedded endomyocardial fragments collected between 19801986 from five patients with the IF and five with the CC form were submitted to semi-thin and thin sectioning and were examined by electron microscopy.

Morphological analysis - The material was photographed at a magnification of $2600 \mathrm{X}$, allowing clear visualization of the myocardial fibre alterations and counting of the archaeal-like bodies.

Immunoelectron microscopy - Immunogold labelling was performed for detection of M. pneumoniae, C. pneumoniae and C5b-9 from nine biopsy fragments. Of these, five were from patients with indeterminate form ( 2 males and 3 females, mean age $33 \pm 13$ years) and four were from patients with chronic Chagas disease with heart failure ( 3 males and 1 female, mean age $38 \pm 22$ years).

Ultrathin sections were submitted to immunogold electron microscopy after etching with $12.5 \%$ ultrafiltered sodium metaperiodate. The slices were incubated with primary antibodies for $20 \mathrm{~h}$. The primary antibodies use were monoclonal M. pneumoniae antibody (clone M2110182, diluted 1:300) from Fitzgerald Industries International Inc, Concord MA, USA, C. pneumoniae antibody (clone RR-402, anti-protein from the outer membrane; non diluted) from Dako, Carpinteria, CA, USA, and anti-Human C5b-9-Terminal Complement Complex (rabbit polyclonal antibody; diluted 1:75) from Calbiochem-Novabiochem Corporation, San Diego, CA, USA). The detection was performed with anti-rabbit IgG (whole molecule) gold conjugate, $10 \mathrm{~nm}$ (1:20) from Sigma Immunochemicals, Saint Louis, MO, USA.

Morphometric analysis - Five photos at 5.500X original magnification were used for morphometry. We counted the mean numbers of dots (colloidal gold particles of 10nm)/ photo, which correspond to an area of $23 \mu \mathrm{m}^{2}$. We also counted two types of rounded structures enclosed by double membranes. These were not clearly stained, suggestive of archaeal bodies. One had mild electron dense lipidic (EDL) content and the other had an apparently clear empty content. We named these structures respectively: EDL and electron lucent content (ELC) bodies.

The sections were observed by electron transmission microscope Philips EM-301 (Eindhoven, Holland).

PCR technique for detection of Archaea and T. cruzi $D N A$ - Five paraffin myocardial fragment blocks from patients with $\mathrm{CC}$ were submitted to the PCR technique for detection of archaeal and T. cruzi DNA. DNA from the fragments was obtained using the PureLink Viral RNA/ DNA Mini Kit (Invitrogen) following the manufacturer's instructions. Five paraffin myocardial fragment blocks from patients with $\mathrm{CC}$ and three normal adult myocardium samples was submitted to the PCR technique for detection of archaeal and T. cruzi DNA. For the isolation and purification of genomic DNA we used the PureLink Viral RNA/DNA Mini Kit (Invitrogen) following the manufacturer's instructions. Archaeal DNA amplification was carried out in $25 \mu \mathrm{L}$ of reaction mixture under the following conditions: $0.2 \mathrm{mM}$ deoxynucleoside triphosphates, $2.5 \mathrm{mM} \mathrm{MgCl} 2,2.5 \mathrm{U}$ of Platinum Taq DNA Polymerase (Invitrogen), $50 \mathrm{pmol}$ of each primer, 1x PCR buffer and $100 \mathrm{ng}$ of DNA, using universal archaeal primers $1100 \mathrm{~F}\left(5^{\prime}\right.$-AGTCAGGTAACGAGCGAG-3') and 1400R (5' -GTGCAAGGAGCAGGGAC-3') (Kudo et al. 1997). PCR was performed in a BioRad DNA Engine thermocycler using the following program: denaturation of DNA at $94^{\circ} \mathrm{C}$ for $3 \mathrm{~min}$, followed by 35 cycles at $94^{\circ} \mathrm{C}$ for $1 \mathrm{~min}, 54^{\circ} \mathrm{C}$ for $1.5 \mathrm{~min}$ and $72^{\circ} \mathrm{C}$ for $1 \mathrm{~min}$, with 10 min at $72^{\circ} \mathrm{C}$ for extension at the end. Genomic DNA of Halobacterium salinarum INCQS A2 (DZMZ 668) (50 ng) was used as a positive control. It was kindly provided by Prof. Maysa Mandetta Clementino from the Bacteria and Archaea Reference Laboratory of the National Institute of Quality Control in Health, Fiocruz, Rio de Janeiro, Brazil. A negative control without DNA was included and the PCR reactions were repeated three times to confirm the reproducibility of the amplification.

T. cruzi DNA amplifications were carried out with 25 $\mu \mathrm{L}$ of reaction mixture under the following conditions: $100 \mathrm{ng}$ of DNA, 50 pmol each primer S34F (5' -TATATTACACCAACCCCAATCGAACC-3') and S67R (5' - TGGTTTTGGGAGGGGSSKTCAAMTTT-3') (Olivares-Villagómez et al. 1998) $0.2 \mathrm{mM}$ of each deoxynucleoside triphosphate, 1x PCR buffer ( $\mathrm{pH} 9.0$ ), 2,5mM $\mathrm{MgCl} 2$ and $2 \mathrm{U}$ of Platinum Taq DNA Polymerase (Invitrogen). Reactions were run in a BioRad DNA Engine thermocycler using the following program: denaturation of DNA at $94^{\circ} \mathrm{C}$ for $6 \mathrm{~min}$, followed by 45 cycles at $94^{\circ} \mathrm{C}$ for $40 \mathrm{sec}, 57^{\circ} \mathrm{C}$ for $1 \mathrm{~min}$ and $72^{\circ} \mathrm{C}$ for $45 \mathrm{sec}$, with $10 \mathrm{~min}$ at $72^{\circ} \mathrm{C}$ for extension. As a positive control, we used genomic DNA from T. cruzi. The mixture was run on a $1 \%$ electrophoresis agarose gel in $1 \mathrm{x}$ TAE buffer $(40 \mathrm{mM}$ Tris base, $20 \mathrm{mM}$ sodium acetate, 1.0 mM EDTA, $p H$ 8.0) with a 100-bp DNA ladder (Invitrogen Carlsbad, CA, USA). The gels were stained with ethidium bromide $(0.5 \mathrm{mg} / \mathrm{mL})$ to visualize the amplified PCR products under UV illumination.

Statistical analysis - The comparison of DNA quantities and archaeal-like bodies between the two clinical groups was performed using the Student $t$-test. The Pearson correlation test was used to determine the relationships between different microbe DNAs or antigens and complement.

\section{RESULTS}

All endomyocardial biopsies were positive for MPDNA and CP-DNA by light microscopy examination. The mean percent areas detected by ISH in the two 
groups of patients are shown in Table I. MP-DNA and CP-DNA were significantly higher in the IF group than in the CC group $(\mathrm{p}<0.001)$. There was a significant positive correlation between MP-DNA and CP-DNA values in the $\mathrm{CC}$ group of patients $(\mathrm{r}=0.64 ; \mathrm{p}=0.005)$ but not in the IF group of patients $(r=-0.28 ; p=0.547)$.

Qualitative and quantitative analysis - Endomyocardial biopsies from the IF group revealed myocardial fibres with well preserved morphology, large amounts of glycogen-like granules in the sarcoplasm and moderate dilatation of T tubules, sarcoplasmic reticulum and intercalated discs, which frequently contained membranous elements in the lumen. Fibrosis in the interstitium usually exhibited mycoplasmal-like forms characterized by only one outer membrane with a rounded or cylindrical shape. Chlamydial bodies characterized by a double membrane and dark homogeneous chromatin were rarely seen in myocardial fibres, macrophages or the extracellular matrix (Fig. 1A, B). Many EDL balls were present in the myocytes either at the subsarcolemal region or more internally. These were similar to lysosomes but enclosed by a barely visibly double external membrane with a darker aspect at the periphery. EDLs were always located near mitochondria and glycogen-like granules (Fig. 2A, B).

A second type of round organelle enclosed by a double membrane was also present. These had ELC with irregular thin flat tubules, an irregular folded external membrane and sometimes contained a large, clear periplasmic space. These EDL and ELC bodies are compatible with archaeal morphology and were sometimes fused to each other (Fig. 2A). EDL and ELC bodies presented variable diameters ranging from around $0.10-1.5 \mu \mathrm{m}$.

In $\mathrm{CC}$ cases, the myocardial fibres presented more intense alterations represented by mitochondrial crystolysis, a clear matrix and dilated reticulum sarcoplasmic organelles frequently presenting irregular membranes in their lumens. There were many foci of myocytolysis usually associated with ELC bodies and a lack of glycogen granules (Fig. 3A, B). There was a severe fibrosis in the interstitium, with mycoplasmal forms among the collagen fibres. There were many forms of ELC among the mononuclear inflammatory cells and in the myocardial fibres. These were associated with mycoplasmal forms and round dark structures that may have been derived from C. pneumoniae elements (Fig. 3C, D). ELC structures were sometimes very large (Fig. 4A, B). Glycogen-like granules were usually absent.

Immunogold electron microscopy counting - Immunoelectron microscopy demonstrated that the monoclonal antibodies anti M. pneumoniae and C. pneumoniae stained surface antigens and free nanolipidic particles suggestive of lipoprotein or lipopolysaccharide from these bacteria, as had been shown in a previous study (Higuchi et al. 2006c). All chagasic EMBs presented high amounts of M. pneumoniae and C. pneumoniae as extracellular antigens, as well as in the extracellular matrix and myocardial fibres. M. pneumoniae and C. pneumoniae were apparently associated with lipid nanovesicles.

Table II shows the mean numbers and standard deviation of gold particles $/ 100 \mu \mathrm{m}^{2}$ detected by immunoelec- tron microscopy and the number of EDL and ELC bodies detected by transmission electron microscopy in both the IF group and the CC group. The unicaudal Student $t$ test showed lower levels of $C$. pneumoniae and higher levels of C5b-9, as well as non-significantly lower levels of $M$. pneumoniae and EDL values, in the $\mathrm{CC}$ group than in the IF group. ELC values were higher in the CC group, without statistical significance. The lack of statistical significance may be linked to the small number of samples analyzed.

Table III shows the correlations between the variables in Table II. The CC group had higher R correlation values than the IF group, with significance only between C5b-9 and C. pneumoniae antigens $(\mathrm{r}=-0.96, \mathrm{p}=0.04)$ and an almost significant negative correlation between EDL and ELC values $(r=-0.97 ; \mathrm{p}=0.06)$.

PCR technique for detection of archaeal and T. cruzi $D N A$ - All five of the CC paraffin myocardial fragment blocks yielded a 300-bp fragment, including the H. salinarum reference strain, after PCR with the universal archaeal primers (Fig. 5). The same samples described above yielded a 122-bp fragment using T. cruzi specific primers (Olivares-Villagómez et al. 1998).

\section{DISCUSSION}

The exact mechanism for the development of chronic dilated cardiopathy in some individuals infected with $T$. cruzi is a still matter of debate. Our results provide evidence that association of mycoplasmal, chlamydial and/or archaeal elements might be related to this phenomenon.

Optical, electron and immunoelectron microscopy showed that high levels of DNA from C. pneumoniae and $M$. pneumoniae and the presence of archaeal-like bodies of the EDL type were associated with IF. Since these values did not correlate with each other and because the morphology was of isolated forms, we conclude that these microbes are not closely associated with IF. Alternatively, fusion of ELC archaeal-like bodies with the microbes described in the IF group was present in the $\mathrm{CC}$ group. An intimal interaction is suggested by the following: (i) the high correlation between CP-DNA and MP-DNA, which correlated negatively with ELC values; (ii) the negative correlation between the numbers of ELC with the numbers of EDL and (iii) the positive correlation between ELC and $\mathrm{C} 5 \mathrm{~b}-9$ values.

The five samples submitted to PCR analysis yielded fragments compatible with the specific primers. Since we did not have enough material to perform PCR in the IF cases, we could not compare this item. Further studies are needed, including a better characterization of EDL and ELC organelles to determine if they present different archaeal genome sequences.

Mycoplasma can either grow symbiotically with eukaryotic cells without producing profound cytotoxicity or it may provoke a marked host response, acting as a super antigen by triggering apoptosis of the $\mathrm{CD}^{+} \mathrm{T}$ cells (Lo 1992). Mycoplasma has the ability to evade the immune system by antigenic variation and resistance to complement lysis (Simmons et al. 2004). However, $M y$ - 


\section{TABLE I}

Percentage of area positive for Mycoplasma pneumoniae DNA (MP-DNA) and Chlamydia pneumoniae DNA (CP-DNA) in endomyocardial biopsies from chagasic patients in indeterminate (IF) or chronic cardiac (CC) forms by in situ hybridization technique in light microscopy and Pearson correlation test

\begin{tabular}{|c|c|c|c|}
\hline Group & $\begin{array}{l}\% \text { MP-DNA } \\
\text { mean }( \pm \text { SD) }\end{array}$ & $\begin{array}{l}\% \text { CP-DNA } \\
\text { mean }( \pm \text { SD) }\end{array}$ & $\begin{array}{l}\text { Correlation } \\
\text { coefficient } \\
\text { MP vs. CP }\end{array}$ \\
\hline $\mathrm{IF}(\mathrm{n}=7)$ & $8.75(4.00)$ & $9.66(4.22)$ & $-0.28(\mathrm{p}=0.547)$ \\
\hline $\mathrm{CC}(\mathrm{n}=17)$ & $2.65(1.64)$ & $3.43(2.65)$ & $0.64(\mathrm{p}=0.005)$ \\
\hline $\mathrm{p}(t$ test $)$ & 0.001 & $<0.001$ & \\
\hline
\end{tabular}

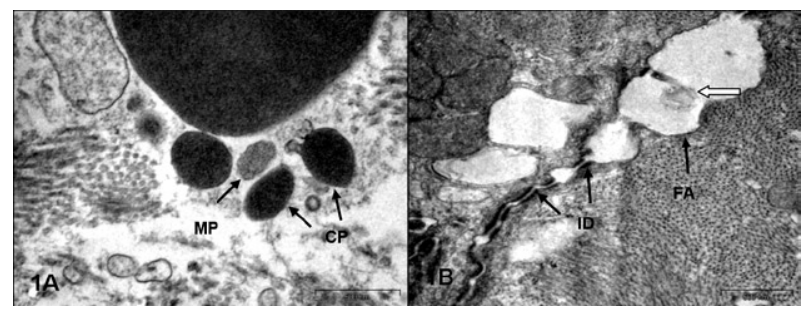

Fig. 1: ultrastructural aspects of an indeterminate asymptomatic form endomyocardial biopsy. A: a group of microbes, suggestive of mycoplasmal and chlamydial bodies, well individualized each other, amidst the fibrosis; B: intercalated disc (ID) with well preserved desmosomes (thin arrows) and dilated fascia adherens containing a membranous element in the lumen (white arrow). CP: Chlamydia pneumoniae; FA: Fascia Adherens MP: Mycoplasma pneumoniae.

coplasma may increase the virulence of other microbes (Dessi et al. 2005) and may induce pro-inflammatory cytokines such as TNF $\alpha$, IL-6 and TGF $\beta$ (Blanchard \& Bebear 2002, Yang et al. 2004), which are related to heart failure (Sharma et al. 2001, Sugamori et al. 2002). Chlamydia is also a frequent symbiont of microbes and has the ability to prevent apoptosis of the host cell (Fan et al. 1998, Sharma \& Rudel 2009). Archaea have antioxidative enzymes, such as superoxidismutase, that promote microbe survival (Cannio et al. 2000) and peptidases and proteasomes that contribute to degradation of aggregation-prone proteins and reduce cellular toxicity in mammalian cells (Yamada et al. 2006).

The presence of M32 family MCP, which is known to be specific to the Archaea and bacteria kingdoms, was described in T. cruzi (Niemirowicz et al. 2007). The authors suggest that the protozoan has acquired these genes by horizontal transfer of an ancestral archaea gene. Consistent with this hypothesis, the T. cruzi MCP has high biochemical similarity with Archaeon P. furiosus (Pfu). Pfu M32 MCP seems to be involved in the utilization of peptides and proteins for the metabolism of the organism (Schul et al. 2003).

Sequences of both the $20 \mathrm{~S}$ proteasomes and $h s I V$ were found in $T$. cruzi, suggesting the presence of en-

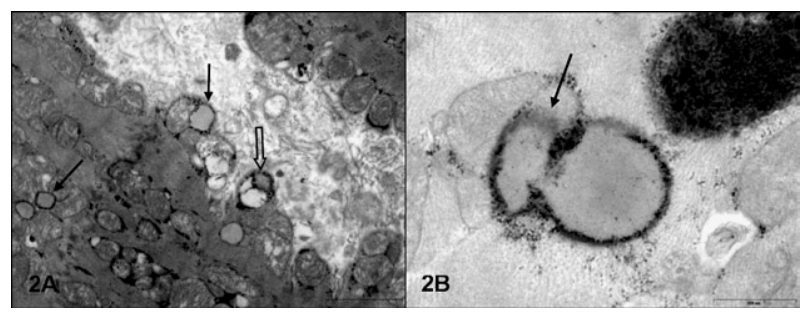

Fig. 2: ultrastructural aspects of an indeterminate asymptomatic form endomyocardial biopsy. A: a panoramic view of a myocardial fiber contain mainly many electron dense lipidic (EDL) bodies (thin arrows) and few electron lucent content bodies, one fused with one EDL body (empty arrow); B: higher magnification of an EDL body divided in two lobes (arrow), exhibiting doubled external membrane, electron dense lipidic internal material darker at the periphery.

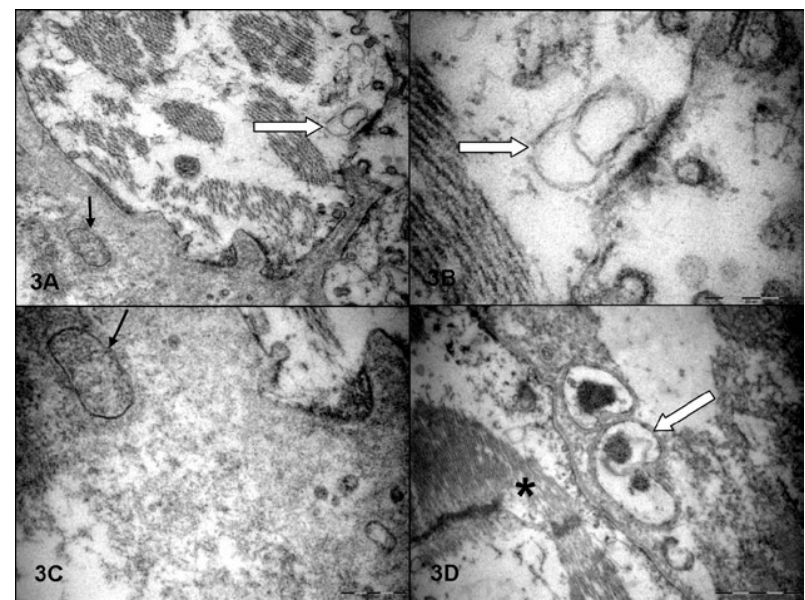

Fig. 3: ultrastructural aspects of a heart failure group endomyocardial biopsy. A: severe myocytolysis of the myocardial fiber. The white arrow indicates an electron lucent content (ELC) structure formed by two compartments, which is in close view in B. The black arrow indicates a mycoplasmal body; C: close view; D: a myocardial fiber with myocytolysis (asterisk), with some apparently symbiotic forms of mycoplasma, ELC and Chlamydia pneumoniae.

dosymbionts, for example, an $\alpha$-proteobacterial progenitor of mitochondria. Alternatively, horizontal gene transfer by temporal association with bacteria within the intestines of insects could account for the presence of these sequences (Gille et al. 2003). T. cruzi undergoes profound morphological changes using proteins from the host cell during its life cycle in the myocardial fibres. An essential role for proteasomes in the degradation of cytoplasmic proteins has been demonstrated (Gonzalez et al. 1996, De Diego et al. 2001).

T. cruzi presents lysosome-related organelles or reservosomes, which contain many enzymes, including carboxypeptidases (Sant'Anna et al. 2008). The lysosome-related organelle or reservosome's morphology is similar to the EDL bodies described in the present study, mainly in IF EMBs. These bodies have a barely visible double membrane, and some types are apparently divided by the presence of two lobes. These findings led us to propose that these EDL bodies could be archaea. 


\section{TABLE II}

Mean numbers and standard deviation of gold particles $/ 100 \mu \mathrm{m}^{2}$ Mycoplasma pneumoniae (MP), Chlamydia pneumoniae (CP) and membrane attack complex (MAC) antigens in immunoeletron microscopy and archaeal-like bodies $/ 100 \mu \mathrm{m}^{2}$ in electron microscopy, in indeterminate (IF) and chronic cardiac (CC) forms

\begin{tabular}{lccccc}
\hline Groups & MP & CP & MAC & EDL & ELC \\
\hline IF $(\mathrm{n}=5)$ & $48 \pm 22$ & $48 \pm 17$ & $56 \pm 13$ & $0.13 \pm 0.04$ & $0.04 \pm 0.04$ \\
CC $(\mathrm{n}=4)$ & $39 \pm 17$ & $17 \pm 8.7$ & $100 \pm 43$ & $0.09 \pm 0.09$ & $0.06 \pm 0.04$ \\
$\mathrm{p}(t$ test $)$ & 0.30 & 0.005 & 0.04 & 0.19 & 0.31 \\
\hline
\end{tabular}

EDL: electron dense lipidic bodies; ELC: electron lucent content bodies.

\section{TABLE III}

Correlation coefficient and $\mathrm{p}$ value between mean numbers of Mycoplasma pneumoniae (MP), Chlamydia pneumoniae (CP) and membrane attack complex (MAC) antigens at the immunoelectron microscopy and electron dense lipidic (EDL) bodies and electron lucent content (ELC) bodies at the electron microscopy

\begin{tabular}{lccccc}
\hline \multicolumn{1}{c}{ CP } & MAC & EDL & ELC \\
\hline MP & IF & $-0.51(0.38)$ & $0.33(0.59)$ & $-0.21(0.73)$ & $-0.04(0.95)$ \\
& CC & $-0.71(0.29)$ & $-0.81(0.19)$ & $0.77(0.23)$ & $-0.85(0.14)$ \\
CP & IF & & $0.007(0.99)$ & $-0.31(0.61)$ & $-0.34(0.57)$ \\
& CC & $-0.96(0.04)$ & $0.34(0.66)$ & $-0.64(0.36)$ \\
MAC & IF & & $0.37(0.53)$ & $-0.60(0.28)$ \\
& CC & & $-0.33(0.67)$ & $0.60(0.40)$ \\
EDL & IF & & & $-0.53(0.34)$ \\
& CC & & & $-0.97(06)$ \\
\hline
\end{tabular}

In CC EMBs we observed ELC archaeal-like bodies. Their morphology is similar to the morphology of those present in the myxoid matrix of vulnerable atheroma plaques that are associated with vessel dilatation and adventitial inflammation in correlation with $C$. pneumoniae and M. pneumoniae elements (Higuchi et al. 2003b, 2006b). The ELCs were in the interstitium among the chronic inflammatory infiltrate, sometimes with a huge periplasmic space containing nanoarchaeal-like bodies. This morphology is similar to that of Ignicoccus hospitalis (Junglas et al. 2008).

The unique ether glycerolipids of Archaea can form vesicles (archaeosomes or liposomes from Archaea) with strong adjuvant activity for MHC class II presentation. The archaeosomes are superior adjuvants that induce a long-term $\mathrm{CD}^{+}$cytotoxic $\mathrm{T}$ cell response to entrapped soluble protein in the absence of help from $\mathrm{CD} 4^{+} \mathrm{T}$ cells (Krishnan et al. 2000). It has been shown that chronic chagasic active myocarditis in $\mathrm{CC}$ patients presents inflammatory infiltrate composed mainly of $\mathrm{CD}^{+} \mathrm{T}$ cells with increased numbers in the presence of T. cruzi an-

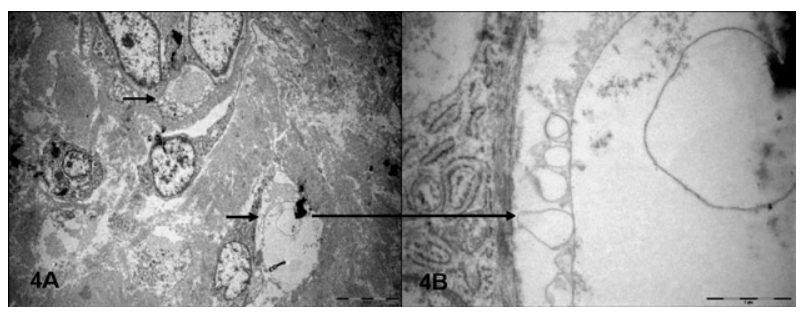

Fig. 4: details of a foci of inflammatory infiltrate in a chronic cardiac case. A: among the mononuclear inflammatory cells, there are some suggestive of Archaeal large bodies characterized by rounded structures surrounded by two membranes, large periplasmic space containing amorphous and granules content and an internal vacuole (small arrows); B: a close view of the periplasmic space with many clear double membrane round structures suggestive of nanoarchaea (large arrow).

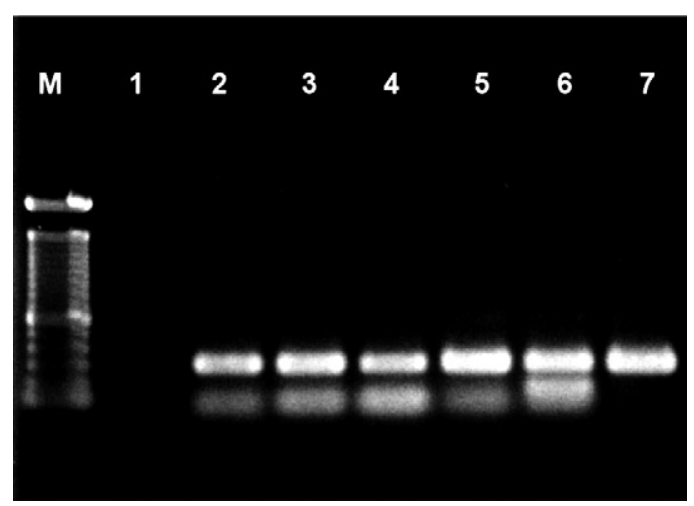

Fig. 5: PCR amplifications of Archaea (primers 1100/1400) in tissues samples of chagasic patients. Lane M: molecular size marker (100-bp DNA ladder); Lane 1: negative control with no added template DNA; Lanes 2-6: tissue samples of chagasic patients; Lane 7: positive control (Halobacterium salinarum).

tigens, and a lack of CD4 ${ }^{+}$T cells (Higuchi et al. 1993b, 1997, Reis et al. 1997). We argue that T. cruzi antigens in archaeosomes may not be the cause of this increased inflammatory infiltrate.

Based on the literature, we may speculate that symbiotic forms involving Mycoplasma, Chlamydia and ELC organelles in the human chronic infection by $T$. cruzi causes increased immune activation by complement deposition and lymphocyte activation leading to the development of myocarditis. However, the presence of non-attached mycoplasmal, chlamydial and EDL archaeal-like bodies leads to reduced myocardial inflammation.

The current view of microbiologists is that prokaryotes' predominant state of being is inside microbial communities. Direct interaction between archaea has been proved to mediate exchange of chromosomal DNA, metabolites or substrates from the cytoplasm of one cell to another (Junglas et al. 2008). The association of different species of microorganisms leads to the development of more resistant and productive new associated forms (Hansen et al. 2007). Also, the presence of one pathogen may inhibit the growth of others. Mycoplasma inhibited the growth of Chlamydia in in vitro studies 
(Van Nerom et al. 2000). Escherichia coli inhibited the growth of T. cruzi (Cortez et al. 2006). High ratios of $M$. pneumoniae/C. pneumoniae were related to an increased amount of growth factors and fibrosis in atheroma plaques (Higuchi et al. 2006a).

Limitations and clinical implications - The present work is a retrospective study with a small number of cases that cannot result in definite conclusions. However, our results may suggest a new frontier of investigation in Chagas cardiopathy pathogenesis, specifically the symbiotic interaction among prokaryotes and a trypanosome.

In conclusion, different amounts of Mycoplasma, Chlamydia and archaeal elements may be implicated in complement activation and may have a role in Chagas disease outcome. IF was associated with isolated forms of these microbes and with the EDL type of archaeallike bodies. CC was associated with fusion of these microbes and ELC archaeal-like bodies in association with increased myocardial complement deposition. These findings open a new direction for pathogenetic studies and the possibility of new prognostic biomarkers in Chagas disease.

\section{REFERENCES}

Aiello VD, Reis MM, Benvenuti LA, Higuchi ML, Ramires JA, Halperin JA 2002. A possible role for complement in the pathogenesis of chronic chagasic cardiomyopathy. J Pathol 197: 224-229.

Andreoli WK, Taniwaki NN, Mortara RA 2006. Survival of Trypanosoma cruzi metacyclic trypomastigotes within Coxiella burnetii vacuoles: differentiation and replication within an acidic milieu. Microbes Infect 8: 172-182.

Belay N, Johnson R, Rajagopal BS, de Macario EC, Daniels L 1988. Methanogenic bacteria from human dental plaque. Appl Environ Microbiol 54: 600-603.

Belay N, Mukhopadhyay B, Conway de Macario E, Galask R, Daniels L 1990. Methanogenic bacteria in human vaginal samples. $J$ Clin Microbiol 28: 1666-1668.

Bellotti G, Bocchi EA, de Moraes AV, Higuchi ML, Barbero-Marcial M, Sosa E, Esteves-Filho A, Kalil R, Weiss R, Jatene A, Pileggi F 1996. In vivo detection of Trypanosoma cruzi antigens in hearts of patients with chronic Chagas' heart disease. Am Heart J 131: 301-307.

Bellotti G, Bocchi EA, de Moraes AV, Higuchi ML, Barbero-Marcial M, Sosa E, Esteves-Filho A, Kalil R, Weiss R, Jatene A, Pileggi F 1998. In vivo detection of Trypanosoma cruzi antigens in hearts of patients with chronic Chagas' heart disease. Am Heart J 135: 550 .

Blanchard A, Bebear CM 2002. Mycoplasmas of humans. In S Razin, R Herrmann (eds.), Molecular biology and pathogenicity of mycoplasmas, Kluwer Academic/Plenum Publisheres, New York, p. $45-71$.

Boetius A, Ravenschlag K, Schubert CJ, Rickert D, Widdel F, Gieseke A, Amann R, Jørgensen BB, Witte U, Pfannkuche O 2000. A marine microbial consortium apparently mediating anaerobic oxidation of methane. Nature 407: 623-636.

Cannio R, Florentino G, Morana A, Ossi M, Bartolucci S 2000. Oxygen: friend or foe? Archaeal superoxide dismutases in the protection of intra- and extracellular oxidative stress. Front Biosci 5: 768-779.

Chimenti C, Del Nonno F, Topino S, Abbate I, Licci S, Paglia MG, Capobianchi MR, Petrosillo N, Frustaci A 2007. Fatal myocardial co-infection by Toxoplasma gondii and Parvovirus B19 in an HIV patient. AIDS 21: 1386-1388.

Cortez M, Atayde V, Yoshida N 2006. Host cell invasion mediated by Trypanosoma cruzi surface molecule gp 82 is associated with Factin disassembly and is inhibited by enteroinvasive Escherichia coli. Microbes Infect 8: 1502-1512.

Cunha-Neto E, Duranti M, Gruber A, Zingales B, De Messias I, Stolf N, Bellotti G, Patarroyo ME, Pilleggi F, Kalil J 1995. Autoimmunity in Chagas disease cardiopathy: biological relevance of a cardiac myosin-specific epitope crossreactive to an immunodominant Trypanosoma cruzi antigen. Proc Natl Acad Sci USA 92: 3541-3545.

De Diego JL, Katz JM, Marshall P, Bessy G, Manning J, Nussenzweig V, Gonzalez J 2001. The ubiquitina-proteasome pathway plays an essential role in proteolysis during Trypanosoma cruzi remodeling. Biochem 40: 1053-1062.

DeLong EF 1992. Archaea in coastal marine environments. Proc Natl Acad Sci USA 89: 5685-5689.

Dessì D, Delogu G, Emonte E, Catania MR, Fiori PL, Rappelli P 2005. Long-term survival and intracellular replication of Mycoplasma hominis in Trichomonas vaginalis cells: potential role of the protozoon in transmitting bacterial infection. Infect Immun 73: $1180-1186$.

Eckburg PB, Lepp PW, Relman DA 2003. Archaea and their potential role in human disease. Infect Immun 71: 591-596.

Fan T, Lu H, Hu H, Shi L, Mcclarty GA, Nance DM, Greenberg AH, Zhong G 1998. Inhibition of apoptosis in Chlamydia infected cells: blockade of mitochondrial cytochrome c release and caspase activation. $J$ Exp Med 187: 487-496.

Gao W, Luquetti AO, Pereira MA 2003. Immunological tolerance and its breakdown in Chagas' heart disease: role of parasitokines. Front Biosci 8: E218-227.

Gille C, Goede A, Schlöetelburg C, Preißner R, Kloetzel PM, Göbel UB, Frömmel C 2003. A comprehensive view on proteasomal sequences: implications for the evolution of the proteasomo. $J \mathrm{Mol}$ Biol 326: 1437-1448.

Gonzalez J, Ramalho-Pinto EJ, Frevert U, Ghiso J, Tomlinson S, Scharfstein J, Corey EJ, Nussenzweig V 1996. Proteasome activity is requires for the stage-specific transformation of a protozoan parasite. J Exp Med 184: 1909-1918.

Halperin JA, Taratuska A, Nicholson-Weller A 1993. Terminal complement complex C5b-9 stimulates mitogenesis in $3 \mathrm{~T} 3$ cell. J Clin Invest 91: 1974-1978.

Hansen SK, Rainey PB, Haagensen JA, Molin S 2007. Evolution of species interactions in a biofilm community. Nature 445: 533-536.

Higuchi ML, Benvenuti LA, Reis MM, Metzger M 2003a. Pathophysiology of the heart in Chagas' disease: current status and new developments. Cardiovasc Res 60: 96-107.

Higuchi ML, Britto T, Reis MM, Barbosa A, Bellotti G, Pereira Barreto AC, Pileggi F 1993a. Correlation between Trypanosoma cruzi parasitism and myocardial inflammatory infiltrate in human chronic chagasic myocarditis: light microscopy and immunohistochemical findings. Cardiovasc Pathol 2: 101-106.

Higuchi ML, Góis JM, Reis MM, Higuchi-Dos-Santos MH, Diament J, Sousa JM, Ramires JA, Oliveira SA 2006a. Co-infection ratios versus inflammation, growth factors and progression of early atheromas. APMIS 114: 338-344.

Higuchi ML, Gutierrez PS, Aiello VD, Palomino S, Bocchi E, Kalil J, Bellotti G, Pileggi F 1993b. Immunohistochemical characterization of infiltrating cells in human chronic chagasic myocarditis: 
comparison with myocardial rejection process. Virchows Arch A Pathol Anat Histopathol 423: 157-160.

Higuchi ML, Higuchi-dos-Santos MH, Pierri H, Palomino S, Sambiase NV, Ramires JAF, Wajngarten M 2002. Mycoplasma pneumoniae and Chlamydia pneumoniae in calcified nodules of aortic stenotic valves. Rev Inst Med Trop Sao Paulo 44: 209-212.

Higuchi ML, Higuchi-dos-Santos MH, Rogério A, Kawakami JT, Bezerra HG, Canzian M 2006b. A role for archaeal organisms in development of atherosclerotic vulnerable plaques and myxoid matrices Clinics 61:473-478.

Higuchi ML, Pierri H, Sesso A, Santos MHH, Timenetski J, Strunz CMC, Fukasawa S, Ramires JAF, Wajngarten M 2006c. Creactive protein and Mycoplasma pneumoniae antigen morphological particles are positively correlated and increased in the serum of elderly atherosclerotic patients. In LV Clark (ed.), New resesarch on atherosclerosis, Nova Science Publisher Inc, New York, p. 1-17.

Higuchi ML, Reis MM, Aiello VD, Benvenutti LA Gutierrez PS, Bellotti G, Pileggi F 1997. Asssociation of an increase in $\mathrm{CD} 8^{+} \mathrm{T}$ cells with the presence of Trypanosoma cruzi antigens in chronic, human, chagasic myocarditis. Am J Trop Med Hyg 56: 485-489.

Higuchi ML, Reis MM, Sambiase NV, Palomino SAP, Castelli JB, Gutierrez PS, Aiello VD, Ramires JA 2003b. Co-infection with Mycoplasma pneumoniae and Chlamydia pneumoniae in ruptured plaques associated with acute myocardial infarction. Arq Bras Cardiol 81: 12-22.

Higuchi ML, Sambiase N, Palomino S, Gutierrez P, Demarchi LM, Aiello V, Ramires JÁ 2000. Detection of Mycoplasma pneumoniae and Chlamydia pneumoniae in ruptured atherosclerotic plaques. Braz J Med Biol Res 33: 1023-1026.

Horn M, Wagner M 2004. Bacterial endosymbionts of free-living amoebae. J Eukaryot Microbiol 51: 509-514.

Jones EM, Colley DG, Tostes S, Lopes ER, Vnencak-Jones CL, McCurley TL 1993. Amplification of a Trypanosoma cruzi DNA sequence from inflammatory lesions in human chagasic cardiomyopathy 1993. Am J Trop Med Hyg 48: 348-357.

Junglas B, Briegel A, Burghardt T, Walther P, Wirth R, Huber H, Rachel R 2008. Ignicoccus hospitalis and Nanoarchaeum equitans: ultrastructure cell-cell interaction, and 3D reconstruction from serial section of freeze-substituted cells and by electron cryotomography. Arch Microbiol 190: 395-408.

Katz JT, Shannon RP 2006. Bacteria and coronary atheroma: more fingerprints but no smoking gun. Circulation 113: 920-922.

Krishnan L, Sad S, Patel GB, Sprott GD 2000. Archaeosomes induce long-term $\mathrm{CD}^{+}$cytotoxic $\mathrm{T}$ cell response to entrapped soluble protein by the exogenous cytosolic pathway, in the absence of $\mathrm{CD}^{+} \mathrm{T}$ cell help. J Immun 165: 5177-5185.

Kudo Y, Nakajima T, Miyaki T, Oyaizu H 1997. Methanogen flora of paddy soils in Japan. FEMS Microbiol Ecol 22: 39-42.

Lepp PW, Brinig MM, Ouverney CC, Palm K, Armitage GC, Relman DA 2004. Methanogenic Archaea and human periodontal disease. Proc Natl Acad Sci USA 101: 6176-6181.

Lo S-C 1992. Mycoplasmas and AIDS. In J Maniloff, RN Mc Elhaney, LR Finch, JB Baseman (eds.), Mycoplasmas, molecular biology and pathogenesis, Am Soc Microbiol, Washington DC, p. $525-545$.

Madigan MT, JM Martinko, J Parker 2000. Prokaryotic diversity: the Archaea. In MT Madigan, JM Martinko, J Parker (eds.), Brock biology of microorganisms, Prentice-Hall Inc, Upper Saddle River, p. $546-572$
Marin-Neto JA, Cunha-Neto E, Maciel BC, Simões MV 2007. Pathogenesis of chronic Chagas heart disease. Circulation 115: 1109-1123.

Miller TL, Wolin MJ 1983. Stability of Methanobrevibacter smithii populations in the microbial flora excreted from the human large bowel. Appl Environ Microbiol 45: 317-318.

Miller TL, Wolin MJ, de Macario EC, Macario AJ 1982. Isolation of Methanobrevibacter smithii from human feces. Appl Environ Microbiol 43: 227-232.

Muller-Eberhard HJ 1988. Molecular organization and function of the complement system. Ann Rev Biochem 57: 321-347.

Niculescu F, Badea T, Rus H 1999. Sublytic C5b-9 induces proliferation of human aortic smooth mucles cells: role of mitogen activated protein kinase and phosphatidylinositol 3-kinase. Atherosclerosis 142: 47-56.

Niemirowicz G, Parussini F, Aguero F, Cazzulo JJ 2007. Two metallocarboxypeptidases from the protozoan Trypanosoma cruzi belong to the M32 family, found so far only in prokaryotes. Biochem J 401: 399-410.

Olivares-Villagómez D, McCurley TL, Vnencak-Jones CL, CorreaOliveira R, Colley DG, Carter CE 1998. Polymerase chain reaction amplification of three different Trypanosoma cruzi DNA sequences from human chagasic cardiac tissue. Am J Trop Med Hyg 59: 563-570.

Raghoebarsing AA, Pol A, van de Pas-Schoonen KT, Smolders AJ, Ettwig KF, Rijpstra WI, Schouten S, Damsté JS, Op den Camp HJ, Jetten MS, Strous M 2006. A microbial consortium couples anaerobic methane oxidation to denitrification. $\mathrm{Na}$ ture 440: 918-921.

Reis MM, Higuchi ML, Benvenuti LA, Aiello VD, Gutierrez PS, Belotti G, Pileggi $F$ 1997. An in situ quantitative immunohistochemical study of cytokines and $\mathrm{IL}-2 \mathrm{R}^{+}$in chronic human chagasic myocarditis: correlation with the presence of myocardial Trypanosoma cruzi antigens. Clin Immunol Immunopathol 83: $165-172$.

Sant'Anna C, Parussini F, Lourenço D, de Souza W, Cazzulo JJ, Cunha-e-Silva NL 2008. All Trypanosoma cruzi developmental forms present lysosome-related organelles. Histochem Cell Biol 130: 1187-1198.

Schul G, Brehm SD, Dallas S, Adams MW 2003. Whole-genome DNA microarray analysis of a hyperthermophile and na archaeon: Pyrococcus fusiosus grown on carbohidrates or peptides. J Bacteriol 185: 3935-3947.

Sharma M, Rudel T 2009. Apoptosis resistance in Chlamydia-infected cells: a fate worse than death? FEMS. Immunol Med Microbiol 55: $154-161$.

Sharma R, Al Nasser FO, Anker SD 2001. The importance of tumor necrosis factor and lipoproteins in the pathogenesis of chronic heart failure. Heart Fail Monit 2: 42-47.

Simmons WL, Denison AM, Dybvig K 2004. Resistance of Mycoplasma pulmonis to complement lysis is dependent on the number of Vsa tandem repeats: shield hypothesis. Infect Immun 72: 6846-6851.

Srinivasan V, Morowitz HJ 2006. Ancient genes in contemporary persistent microbial pathogens. Biol Bull 210: 1-9.

Sugamori T, Ishibashi Y, Shimada T, Takabashi N, Sakane T, Ohata S, Kunizawa Y, Inoue S, Nakamura K, Ohta Y, Shimizu H, Katoh H, Oyake N, Murakami Y, Hashimoto M 2002. Increased nitric oxide in proportion to the severity of the heart failure in patients with dilated cardiomyopathy: close correlation of tumor necrosis 
factor-alphawith systemic and local production of nitric oxide. Circ J 66: 627-632.

Van Nerom A, Ducatelle R, Charlier G, Haeseebrouck F 2000. Interaction between turkey monocytes and avian - Chlamydia psittaci - in the presence of Mycoplasma sp.: the importance of nitric oxide. Dev Comp Immunol 24: 417-432.

Walder G, Gritsch W, Wiedermann CJ, Pölzl G, Laufer G, Hotzel H, Berndt A, Pankuweit S, Theegarten D, Anhenn O, Oehme A, Dier- ich MP, Würzner RC 2007. Co-infection with two Chlamydophila species in a case of fulminant myocarditis. Care Med 35: 623-626.

Yamada S, Niwa J, Ishigaki S, Takahashi M, Ito T, Sone J, Doyu M, Sobue G 2006. Archaeal proteasomos effectively degrade aggregation-prone proteins and reduce cellular toxicities in mammalian cells. J Biol Chem 281: 23842-2351.

Yang J, Hooper WC, Phillips DJ, Talkington DF 2004. Cytokines in Mycoplasma pneumoniae infections. Cytokine Growth Factor Rev 15: 157-168. 